\title{
ISLAMIC WORLDVIEW DI DUNIA PENDIDIKAN
}

\author{
Syaiful Anam ${ }^{1}$, Aris Munandar ${ }^{2}$, Listiatul Wahada ${ }^{3}$ \\ Sekolah Tinggi Ilmu Tarbiyah Madani Yogyakarta
}

\begin{abstract}
Abstrak
Islamic worldview adalah pandangan hidup yang dimulai dari konsep ke- Esaan Tuhan (syahadad) yang berimplikasi pada keseluruhan kegiatan manusia di dunia.Islamic worldview diartikan juga sebagai visi tentang realitas dan kebenaran, yang terbaca oleh mata hati kita dan yang menerangkan tentang hakikat wujud yang sesungguhnya, sebab totalitas dunia wujud itulah yang diproyeksikan Islam.
\end{abstract}

Profesionalisasi dunia pendidikan yang terintegrasi dengan Islamic worldview mengandung arti peningkatan segala daya dan usaha dalam rangka pencapaian secara optimal layanan yang akan diberikan kepada masyarakat. Pengembangan dunia pendidikan dimaksudkan untuk merangsang, memelihara, dan meningkatkan kompetensi siswa dalam memecahkan masalah-masalah pendidikan dan pembelajaran yang berdampak pada peningkatan mutu hasil belajar siswa dan memiliki pandangan hidup Islami.

Hal yang paling utama yang harus diperhatikan dalam membangun peradaban umat adalah cara pandang terhadap Islam. Artinya pandangan umat Islam harus menggunakan pandangan atau cara berpikir yang berasas Islam, menghadirkan Islam dalam semua lini kehidupan baik Politik, Ekonomi, Pendidikan, Sains dan sektorsektor lainnya. Sebab Islam yang bersumber dari Alquran membahas secara universal tentang politik. Tatanan pemerintahan yang sesuai agar bisa menjalankan syariat, bagaimana menata kehidupan yang baik dan wilayahnya bisa berdaulat dan bermartabat juga rakyatnya bisa sejahtera.

Peradaban Islam adalah peradaban yang dibangun oleh ilmu pengetahuan Islam yang dihasilkan dari pandangan hidup Islam.

\footnotetext{
${ }^{1}$ Dosen Sekolah Tinggi Ilmu Tarbiyah Madani Yogyakarta.

2Dosen Sekolah Tinggi Ilmu Tarbiyah Madani Yogyakarta.

${ }^{3}$ Mahasiswa Sekolah Tinggi Ilmu Tarbiyah Madani Yogyakarta.
} 
membangun peradaban Islam harus dimulai dengan membangun pemikiran umat Islam, meskipun tidak berarti kita berhenti membangun bidang-bidang lain. Mengubah Islamic world view/framework atau cara pandang umat kepada cara pandang Islam (prinsip Islam) adalah kunci bangkitnya peradaban Islam. Sebab peradaban itu muncul dari pandangan yang melahirkan tindakan dan berbuah Ilmu Pengetahuan.

\section{Kata kunci; Dunia pendidikan, peradaban Islam, islamic worldview}

\section{Abstract}

Islamic worldview is a view of life that starts from the concept of God's essence (shahada) which has implications for the overall human activities in the world. Islamic worldview is also interpreted as a vision of reality and truth, which is read by the eyes of our hearts and which explains the true nature of being, because the totality of the world is what Islam projects.

The professionalization of the world of education that is integrated with Islamic worldview implies an increase in all power and effort in order to achieve optimal services that will be provided to the community. The development of the world of education is intended to stimulate, maintain, and improve student competence in solving problems of education and learning that have an impact on improving the quality of student learning outcomes and having an Islamic outlook on life.

The most important thing that must be considered in developing civilization is the perspective on Islam. This means that the views of Muslims must use views or ways of thinking that are based on Islam, presenting Islam in all lines of life, both Politics, Economics, Education, Science and other sectors. Because Islam originating from the Koran discusses universally about politics. The appropriate government order in order to be able to carry out Shari'a, how to organize a good life and its territory can be sovereign and dignified as well as its people can prosper.

Islamic civilization is a civilization built by Islamic science that is produced from the Islamic worldview. building Islamic civilization must begin with building the thoughts of Muslims, although that does 
not mean we stop building other fields. Changing the Islamicworldview / framework or the way people view Islamic views (Islamic principles) is the key to the rise of Islamic civilization. Because that civilization emerged from a view that gave birth to action and fruitfulness in Science.

Keywords; The world of education, Islamic civilization, Islamic worldview

\section{A. Pendahuluan}

Negara Islam hari ini jika boleh dikatakan seperti anak ayam yang kehilangan Induknya, walaupun sebagian ahli berpendapat kemunduran umat Islam dikarenakan banyak faktor diantaranya; ada faktor eksternal dan internal, namun faktor tersebut tidak penulis bahas disini. Karena yang harus dipahami oleh umat Islam sekarang adalah bagaimana caranya memulai dan membangkitakan kembali marwah Islam kepentas dunia, yaitu dengan mengusung trilogi; mencipta kedamaian umat, memberikan kesejahteraan dan melahirkan peradaban.

Kondisi ini menggiring kita yang satu aqidah turut berduka dan ikut mencari solusi, apa yang salah dengan Islam sekarang hingga bisa terjadi hal-hal yang disebutkan di atas. kondisi ini terjadi antara lain, karena ketegangan sosial atau kekacauan politik, ekonomi, pendidikan, budaya dan lain sebagainya. Artinya Pembangunan Ilmu Pengetahuan Islam dalam melahirkan masyarakat yang sehat dan beradab sedang dalam masalah. Terus sebenarnya siapa yang salah, apakah konsep Islam, ataukah orang 
Islam yang mungkin sudah jauh dan keliru dalam memahami Islam yang sebenarnya.

Mengapa negara Islam sekarang pudar eksistensinya dalam skala ilmu pengetahuan dunia? Padahal Islam adalah suatu ajaran yang sangat konsen dan menyeru umatnya untuk mencari ilmu, Alloh mengangkat derajat orang yang beriman dan yang memiliki ilmu pengetahuan (QS. Al-Mujadalah: 11).

Dengan ilmu pula manusia (Nabi Adam 'Alaihissalam) lebih mulia dan tinggi derajatnya dari pada makhluk lain tak terkecuali malaikat sekalipun. Lalu dimanakah letak kemuliaan itu sekarang, Ironisnya, dewasa ini yang terjadi pada umat Islam di seantero bumi sana adalah penyerangan, pembantaian umat, pertikaian antar ideologi notabennya juga dalam tubuh umat Islam sendiri dan pada akhirnya melahirkan peperangan dalam satu aqidah. Sekali lagi, dimanakah letak "Kewibaan umat Islam ?"

Kondisi ini terjadi antara lain, karena ketegangan sosial atau kekacauan politik, ekonomi, pendidikan, budaya dan lain sebagainya. Artinya Pembangunan Ilmu Pengetahuan Islam dalam melahirkan masyarakat yang sehat dan beradab sedang dalam masalah. Terus sebenarnya siapa yang salah, apakah konsep Islam, ataukah orang Islam yang mungkin sudah jauh dan keliru dalam memahami Islam yang sebenarnya.

Pengakuan Gutas bahwa peradaban Islam "disusun sesuai dengan agama yang diwahyukan kepada Muhammad", Islam adalah bukti bahwa peradaban Islam disusun berdasarkan din 
Islam, dan karena itu sangat sesuai disebut sebagai peradaban. Di dalam peradaban itu terdapat kedamaian ${ }^{4}$.

Ketika menjalankan agama Islam dengan benar dan universal maka akan menciptakan peradaban yang dapat mensejahterakan penghuni pada tempat tersebut. Agama Islam adalah agama yang bersumber dari wahyu tuhan berisi anjuran, larangan dan pedoman kehidupan diwahyukan kepada nabi Muhammad dan pada akhirnya dikodifikasikan dalam bentuk kitab suci Alquran. Jadi Alquran itu adalah wahyu dari tuhan sebagai bentuk petunjuk dalam menjalankan kehidupan.

\section{B. Pembahasan}

\section{Pengertian worldview}

Worldview adalah term yang dipakai dalam bahasa Inggris, atau dalam bahasa Jerman yang semakna yakni, weltanschauung dengan arti, "pandangan hidup" atau "pandangan dunia", dengan pengertiannya tentang realitas sebagai suatu keseluruhan atau pandangan tentang kosmos. Pandangan umum tentang dunia ini berarti pandangan yang menyangkut soal hakikat, nilai, arti, dan tujuan dunia serta hidup manusia.

Sebenarnya istilah umum dari worldview hanya terbatas pada pengertian ideologis, sekuler, kepercayaan animistis, atau seperangkat doktrin-doktrin teologis dalam kaitannya dengan visi keduniaan. Artinya worldview dipakai untuk

4(Demitri Gutas, Greek Thought, Arabic Culture,London: Routledge, 1988). Hal. 10 
menggambarkan dan membedakan hakikat sesuatu agama, peradaban, atau kepercayaan. Terkadang ia juga digunakan sebagai metode pendekatan ilmu perbandingan agama. Namun karena terdapat agama dan peradaban yang memilikisp ektrum pandangan yang lebih luas dari sekadar visi keduniaan, maka makna pandangan hidup diperluas. Tapi kosa kata bahasa Inggris tidak memiliki istilah yang tepat untuk mengekspresikan visi yang lebih luas dari sekadar realitas keduniaan selain dari kata-kata worldview. Oleh sebab itu cendekiawan Muslim mengambil kata-kata worldview (untuk ekspresi bahasa Inggris) untuk makna pandangan hidup yang spektrumnya menjangkau realitas keduniaan dan keakhiratan dengan menambah kata sifat "Islam". Namun dalam bahasa Islam para ulama mengekspresikan konsep ini dengan istilah yang khas yang berbeda antara satu dengan yang lain. ${ }^{5}$

Karena pandangan hidup adalah suatu konsep yang dapat digunakan untuk menggambarkan cara pandang manusia secara umum tanpa melihat bangsa atau agama, maka beberapa definisi tentang worldview yang juga menggambarkan luas dan sempitnya spektrumnya dapat dikemukanan di sini. Menurut Ninian Smart, misalnya, worldview adalah kepercayaan, perasaan dan apa-apa yang terdapat dalam

\footnotetext{
5Joseph A Schumpeter,.1942. Capitalism, Socialism and Democarcy, (New York : Charles Sribner's sons, 1942). hal. : 121
} 
pikiran orang yang befungsi sebagai motor bagi keberlangsungan dan perubahan sosial dan moral. ${ }^{6}$. Hampir serupa dengan Smart, Thomas F. Wall mengemukakan bahwa worldview adalah sistem kepercayaan asas yang integral tentang hakikat diri kita, realitas, dan tentang makna eksistensi (An integrated system ofbasic beliefs about the nature of yourself, reality, and the meaning ofexistence $)^{7}$. Lebih luas dari kedua definisi di atas Prof. Alparslanoleh mengartikan worldview sebagai asas bagi setiap perilaku manusia, termasuk aktivitas-aktivitas ilmiah dan teknologi. Setiap aktivitas manusia akhirnya dapat dilacak pada pandangan hidupnya, dan dalam pengertian itu, maka aktivitas manusia dapat direduksi menjadi pandangan hidup. ${ }^{8}$

Ada tiga poin penting dari definisi di atas, yaitu bahwa worldview adalah motor bagi perubahan sosial, asas bagi pemahaman realitas dan asas bagi aktivitas ilmiah. Dalam konteks sains, hakikat worldview dapat dikaitkan dengan konsep "perubahan paradigma" (ParadigmShift) Thomas S Kuhn (kuhn, yang oleh Edwin Hung juga dianggap sebagai weltanschauung Revolution. Sebab paradigma menyediakan konsepnilai, standar-standar dan metodologi-metodologi, atau

\footnotetext{
${ }^{6}$ NinianSmart ,2000. Worldview, Crosscultural Explorations of Human Belief, (New York: Charles Sribner's sons, 2000 (nd). Hal. 1-2

7Thomas F Wall..Thinking Critically About Philosophical Problem, A Modern Wardsworth. (London: Harper \& Brothers Publishers, 2001). Hal. 532

${ }^{8}$ Alparslan Acikgence," The Framework for A history of Islamic Philosophy", Al-Shajarah, journal of The International Institute of Islamic Thought and Civilization.vol.1. Nos. 1\&2. Kualalumpur : ISTAC. 1996.Hal. 6
} 
ringkasnya merupakan worldview dan framework konseptual yang diperlukan untuk kajian sains. ${ }^{9}$ Namun dari definisi di atas setidaknya kita dapat memahami bahwa worldview adalah identitas untuk membedakan antara suatu peradaban dengan yang lain. Bahkan dari dua definisi terakhir menunjukkan bahwa worldview melibatkan aktivitas epistemologis manusia, sebab ia merupakan faktor penting dalam aktivitis penalaran manusia.

\section{Elemen Worldview}

Sebagai sebuah sistem yang secara definitif begitu jelas,worldview atau pandangan hidup memiliki karakteristik tersendiri yang ditentukan oleh beberapa elemen yang menjadi asas atau tiang penyokongnya. Antara satu pandangan hidup dengan pandangan hidup lain berbeda karena berbeda elemennya atau karakteristiknya. Demikian pula perbedaan definisi tentang worldview juga mempengaruhi penentuan elemen di dalamnya. Di sini akan dibandingkan secara singkat antara elemen pandangan hidup dalam perspektif pemikir Barat dan pemikiran Muslim. Menurut Thomas suatu pandangan hidup ditentukan oleh pemahaman individu terhadap enam bidang pembahasan yaitu: 1) Tuhan, 2) Ilmu, 3)

Realitas, 4) Diri, 5) Etika, dan 6) Masyarakat. ${ }^{10}$ Seperti

${ }^{9}$ Edwin Hung. The Nature of Science: Problem and Perspectives, (California:Thomson Learning, 1997). Hal. 340

10Wall,Thomas F Wall..Thinking Critically About Philosophical Problem, A Modern Wardsworth. (London: Harper \& Brothers Publishers, 2001). Hal.16 
disebutkan di atas bagi Thomas elemen-elemen pandangan hidup di atas merupakan suatu sistem yang integral, di mana antara satu konsep berkaitan dengan konsepyang lain secara sistemik.

Tidak banyak cendekiawan muslim yang menggambarkan elemen-elemen pandangan hidup Islam secara terperinci. Sheykh Atif al-Zayn, misalnya, tidak merincikan elemen pandangan hidup Islam, namun hanya mengajukan karakteristik yang membedakan antara pandangan hidup Islam dari pandangan hidup lain. Karakteristik itu hanya tiga: 1) berasal dari wahyu Allah, 2) berdasarkan konsep (dîn) yang tidak terpisah dari negara, dan 3) kesatuan antara spiritual dan material. ${ }^{11}$ Sebagaimana Sheykh Atif al-Zayn, Sayyid Qutb juga melihat bahwa pandangan hidup Islam itu menyeluruh dan tidak mempunyai elemen atau bagian (juz'). Ia adalah keseluruhan sisi dan sempurna karena kesempuranaan sisi-sisinya. Bahkan pandangan hidup Islam bukan ciptaan manusia, akal manusia tidak dapat menciptakannya, karena ia berasal dari Allah. ${ }^{12} \mathrm{Di}$ sini penekanan pada aspek keilahian cukup menonjol, sedangkan aspek keilmuan tidak nampak. Seakan-akan pandangan hidup Islam sama saja dengan wahyu yang tanpa

\footnotetext{
11Shaykh Âthif Al-Zayn,. al-Islâm wa Idulujiyyat al-Insân, (Beirut: Dâr al- Kitâb alLubnânî, 1989). Hal. 11-12

${ }^{12}$ Qutb, M. Sayyid Quthb, , al-Tashawwur al-Islâmî wa Muqawamâtuhû, (Cairo: al-Babi al- Halabi, 1962). Hal. 30-34
} 
penjelasan keilmuan. Berbeda dari ketiga ulama di atas, Naquib al-Attas melihat worldview Islam memiliki elemen yang sangat banyak dan bahkan yang merupakan jalinan konsep-konsep yang tak terpisahkan. Di antara yang paling utama adalah 1) konsep tentang hakikat Tuhan, 2) konsep tentang wahyu (al-Qur'an), 3) konsep tentang penciptaan, 4) konsep tentang hakikat kejiwaan manusia, 5) konsep tentang ilmu, 6) konsep tentang agama,7) konsep tentang kebebasan, 8) konsep tentang nilai dan kebajikan, 8) konsep tentang kebahagiaan, 9) dan lain sebagainya. ${ }^{13}$

Di sini al-Attas menekankan pada pentingnya konsep sebagai elemen pandangan hidup Islam. Konsep-konsep ini semua saling berkaitan antara satu sama lain membentuk sebuah struktur konsep yang sistemik. Elemen yang disampaikan Sheykh Atif, Sayyid Qutb dan Syed Naquib alAttas berbeda dalam penekanannya, tapi ketiganya mempunyai kesamaan visi, yaitu bahwa pandangan hidup Islam berpusat pada akidah atau kepercayaan kepada Tuhan. Namun apa yang membedakan pandangan hidup Islam dari pandangan hidup lain mereka berbeda-beda. Shyakh Atif dan Sayyid Qutb perbedaannya adalah pada asal atau sumber

\footnotetext{
13S.M.N Al-Attas.. "The Worldview of Islam, An Outline, Opening Adress", dalam Sharifah Shifa al-Attas (ed.), Islam and the Challenge of Modernity, Proceeding of the inaugural Symposium on Islam and the Challenge of Modernity: Historical and Contemporary Context, Kuala Lumpur Agustus, 1-5, 1994, Kuala Lumpur: ISTAC. Hal.29
} 
pandangan hidup tersebut, sedangkan al-Attas melihat secara lebih konseptual dan praktis.

Secara praktis konsep-konsep penting yang diajukan alAttasitu dapat berguna bagi penafsiran makna kebenaran (truth) dan realitas (reality). Bagi al-Attas untuk menentukan sesuatu itu benar danriel dalam setiap kebudayaan berkaitan erat dengan sistem meta-fisika masing-masing yang terbentuk oleh worldview. ${ }^{14}$ Di sini kita melihat konsep pandangan hidup al-Attas dengan jelas menekankan aspek epistemologis. Dan ini cukup signifikan dalam era moderninasidan globalisasi disaat mana terjadi disolusi konsep yang cenderung melemahkan pandangan hidup Islam yang kekuatannya tertelak pada struktur konsepnya.

Untuk melihat sisi lain yang lebih detail mengenai hal itu, kitapaparkan gambaran al-Attas tentang elemen penting yang menjadikarakter utama pandangan hidup Islam. Elemen penting pandanganhidup Islam itu digambarkan dalam poinpoin berikut ini. ${ }^{15}$ Pertama,dalam pandangan hidup Islam realitas dan kebenaran dimaknaiberdasarkan pada kajian

\footnotetext{
14S.M.N Al-Attas.. "The Worldview of Islam, An Outline, Opening Adress", dalam Sharifah Shifa al-Attas (ed.), Islam and the Challenge of Modernity, Proceeding of the inaugural Symposium on Islam and the Challenge of Modernity: Historical and Contemporary Context, Kuala Lumpur Agustus, 1-5, 1994, Kuala Lumpur: ISTAC. Hal. ix

15S.M.N Al-Attas.. "The Worldview of Islam, An Outline, Opening Adress", dalam Sharifah Shifa al-Attas (ed.), Islam and the Challenge of Modernity, Proceeding of the inaugural Symposium on Islam and the Challenge of Modernity: Historical and Contemporary Context, Kuala Lumpur Agustus, 1-5, 1994, Kuala Lumpur: ISTAC. Hal. 28-29
} 
metafisika terhadap dunia yang nampak(visible world) dan yang tidak nampak (invisible world). Kedua,pandangan hidup Islam bercirikan pada metode berpikir yangtawhîdî (integral). Ketiga, pandangan hidup Islam bersumber padawahyu yang diperkuat oleh agama (dîn) dan didukung oleh prinsipakal dan intuisi. Keempat, elemen-elemen pandangan hidup Islamterdiri utamanya dari konsep Tuhan dan diikuti oleh elemen lainyang berpusat pada konsep Tuhan tersebut.

\section{Proses Munculnya Worldview}

Menurut Alparslan suatu worldview terbentuk dalam pikiran individu secara perlahan-lahan, bermula dari akumulasi konsep-konsep dan sikap mental yang dikembangkan oleh seseorang sepanjang hidupnya, sehingga akhirnya membentuk mental framework atau worldview. ${ }^{16}$ Secara epistemologis proses berfikir ini sama dengan cara kita mencari dan memperoleh ilmu, yaitu akumulasi pengetahuan a priori dan a posteriori. Proses itu dapat dijelaskan sebagai berikut; ilmu pengetahuan yang diperoleh seseorang itu sudah tentu terdiri dari berbagai konsep dalam bentuk ide-ide, kepercayaan, aspirasi, dan lain-lain yang semuanya membentuk suatu totalitas konsep yang saling berkaitan dan terorganisasikan dalam suatu jaringan.

\footnotetext{
${ }^{16}$ Alparslan Acikgence,"The Framework for A history of Islamic Philosophy", Al-Shajarah, journal of The International Institute of Islamic Thought and Civilization. vol.1. Nos. 1\&2. Kualalumpur : ISTAC. 1996.Hal. 6
} 
Jaringan ini membentuk struktur berfikir yang koheren dan dapat disebut sebagai achitectonic whole, yaitu suatu keseluruhan yang salingberhubungan. Oleh sebab itu, worldview seseorang tersebut terbentuk tidak lama setelah pengetahuan yang diperoleh dalam bentuk konsep-konsep membentuk suatu keseluruhan yang saling berhubungan. ${ }^{17}$ Architectonic network ini kebanyakan terbentuk oleh pendidikan serta masyarakat, dan dalam Islam dibentuk utama oleh agama.

Proses pembentukan worldview dalam kebudayaan atau masyarakat pada umumnya sama seperti yang dijelaskan di atas, tapi terdapat beberapa perbedaan teknis, khususnya dalam kaitannya dengan kegiatan keilmuan. Jika dalam worldview suatu masyarakat tidak terdapat konsep ilmu atau konsep-konsep lain yang berkaitan, worldview itu hanya berperan sebagai kondisi berfikir yang tidak menjamin adanya kegiatan ilmiah atau penyebaran ilmu pengetahuan di masyarakat. Worldview seperti ini memerlukan apa yang disebut scientific conceptual scheme (kerangka konsep keilmuan), yang dengan itu kegiatan keilmuan dapat dilaksanakan.

Worldview dalam suatu masyarakat jika telah memiliki konsep ilmu atau konsep-konsep lain yang berkaitan, worldview itu akan berkembang melalui cara-cara ilmiah. Melihat kedua

\footnotetext{
${ }^{17}$ Alparslan Acikgence,"The Framework for A history of Islamic Philosophy", Al-Shajarah, journal of The International Institute of Islamic Thought and Civilization. vol.1. Nos. 1\&2. Kualalumpur : ISTAC. 1996.Hal. 7
} 
proses pembentukan dan pengembangan worldview yang seperti ini, worldview dapat dibagi menjadi natural worldview dan transparent worldview. Disebut demikian karena yang pertama terbentuk secara alami sedangkan yang kedua terbentuk oleh suatu kesadaran berfikir 18

Transparent worldview dalam disseminasi ilmu pengetahuan tidak selalu menggunakan cara-cara ilmiah dalam scientific conceptual scheme (kerangka konsep keilmuan), yaitu mekanisme canggih yang mampu melahirkan pengetahuan ilmiah dan melahirkan pandangan hidup ilmiah (scientific worldview). ${ }^{19}$ Terdapat pula transparent worldview yang lahir tidak melalui konsep keilmuan, meskipun subtansinya tetap bersifat ilmiah. Pandangan yang lahir dengan cara itu adalah pandangan hidup Islam (Islamic worldview). Sebab pandangan hidup Islam (Islamic worldview) tidak bermula dari adanya suatu masyarakat ilmiah yang mempunyai mekanisme yang canggih untuk menghasilkan pengetahuan ilmiah.

Pandangan hidup Islam (Islamic worldview) dirancang oleh Nabi Muhammad SAW di Mekkah melalui penyampaian wahyu Allah SWT dengan cara-cara yang khas. Setiap kali Nabi menerima wahyu yang berupa ayat-ayat al-Qur'an, beliau

\footnotetext{
18Alparslan Acikgence, "The Framework for A history of Islamic Philosophy", AlShajarah, journal of The International Institute of Islamic Thought and Civilization. vol.1. Nos. 1\&2. Kualalumpur : ISTAC. 1996.Hal.13-14

${ }^{19}$ Alparslan Acikgence, "The Framework for A history of Islamic Philosophy", AlShajarah, journal of The International Institute of Islamic Thought and Civilization. vol.1. Nos. 1\&2. Kualalumpur : ISTAC. 1996.Hal.10-19).
} 
menjelaskan dan menyebarkannya ke masyarakat. Cara-cara ini tidak sama dengan cara-cara yang ada pada scientific worldview. Oleh karena itu, Prof. Alparslan menamakan Islamic worldview dengandengan 'quasi-scientific worldview ${ }^{20}$

Proses pembentukan worldview melalui penyebaran ilmu pengetahuan di atas akan lebih jelas lagi jika dilihat dari proses pembentukan elemen-elemen pokok yang merupakan bagian dari struktur worldview itu serta fungsi di dalamnya. Seperti yang dijelaskan di atas bahwa worldview dibentuk oleh jaringan berfikir yang berupa keseluruhan yang saling berhubungan. Namun, ia tidak merepresentasikan suatu totalitas konsep dalam pikiran kita. Ketika akal seseorang menerima pengetahuan, terjadi proses seleksi yang alami, yakni pengetahuan tertentu diterima dan pengetahuan yang lain ditolak. Pengetahuan yang diterima oleh akal kita akan menjadi bagian dari struktur worldview yang dimilikinya.

Alparslan mengategorikan struktur worldview menjadi lima yakni; struktur tentang kehidupan, tentang dunia, tentang manusia, tentang nilai, dan struktur tentang pengetahuan. ${ }^{21}$ Proses terbentuknya struktur dalam worldview ini bermula dari struktur tentang kehidupan, yang didalamnya termasuk cara-

\footnotetext{
20Alparslan Acikgence, "The Framework for A history of Islamic Philosophy", AlShajarah, journal of The International Institute of Islamic Thought and Civilization. vol.1. Nos. 1\&2. Kualalumpur : ISTAC. 1996.Hal. 19

${ }^{21}$ Alparslan Acikgence, "The Framework for A history of Islamic Philosophy", Al-Shajarah, journal of The International Institute of Islamic Thought and Civilization.vol.1. Nos. 1\&2.Kualalumpur : ISTAC. 1996.Hal. 20-26
} 
cara manusia menjalani kegiatan kehidupan sehari-hari, sikapsikap individual dan sosialnya, dan sebagainya. Struktur tentang dunia adalah konsepsi tentang dunia tempat manusia hidup. Struktur tentang ilmu pengetahuan adalah pengembangan dari struktur dunia dalam transparent worldview. Gabungan dari struktur kehidupan, dunia dan pengetahuan ini melahirkan struktur nilai, tempat konsepkonsep tentang moralitas berkembang. Setelah keempat struktur itu terbentuk dalam worldview seseorang secara transparent, struktur tentang manusia akan terbentuk secara otomatis.

Proses akumulasi kelima struktur di atas dalam pikiran seseorang tidak selalu bertautan seperti yang disebutkan, tetapi yang terpenting kelima struktur itu pada akhirnya menjadi suatu kesatuan konsepsi dan berfungsi tidak saja sebagai kerangka umum dalam memahami segala sesuatu termasuk diri kita sendiri, tapi juga mendominasi cara berfikir kita. Di sini dalam konteks lahirnya ilmu pengetahuan di masyarakat, struktur ilmu pengetahuan merupakan asas utama dalam memahami segala sesuatu. Ini berarti bahwa teori atau konsep apapun yang dihasilkan oleh seseorang dengan pandangan hidup tentunya akan merupakan refleksi dari struktur-struktur di atas.

Teori ini berlaku secara umum pada semua kebudayaan dan dapat menjadi landasan yang valid dalam 
menggambarkan timbul dan berkembangnya worldview manapun, termasuk pandangan hidup Islam (Islamic worldview). Berarti, kegiatan keilmuan apapun baik dalam kebudayaan Barat, Timur maupun peradaban Islam dapat ditelusuri dari worldview masing-masing.

\section{Worldview dalam Tataran Ideologi}

Worldview dalam pengertian yang luas adalah menyangkut eksistensi absolut, tujuan dan makna dunia. Ditinjau dari pemecahan masalah, akan terdapat dua jenis pokok worldview yakni; materialis dan idealis. Disampingdua jenis ini perlu dibedakan dua jenis lain, yakni prailmiah dan ilmiah, irrasional dan rasional. Worldview ilmiah merupakan keyakinan yang tumbuh secara akalbudi kodrati, yang mendapat wujudnya dalam metafisika. Ada yang mengatakan bahwa worldview mempunyai dasar yang irrasional. Pandangan ini dipengaruhi oleh agnotisisme. Adapun worldview yang prailmiah kadang-kadang mendapat padanan pada istilah falsafah atau mabda' yang diistilahkan oleh Prof. Alparslan. Maka dalam hal tersebut worldview dapat digolongkan kepada tataran ideologi.

Istilah ideologi dipergunakan dalam pengertian yang bermacam-macam. Istilah ideologi adalah sebuah kata yang terdiri dari Ideo dan Logi. Kata ideo berasal dari bahasa Yunani eidos, dalam bahasa latin idea, yang berarti "pengetian", "ide" atau "gagasan". Kata kerja dalam bahasa Yunani oida yang 
berarti mengetahui, melihat dengan budi. Dalam bahasa Jawa akan dijumpai kata idep dengan arti tahu, melihat. Kata logi berasal dari bahasa Yunani logos, yang berarti "gagasan", "pengertian", "kata”, dan "ilmu". Jadi secara etimologis dapat diterangkan bahwa ideologi berarti "pengetahuan tantang ideide" $^{\prime \prime}$, science of ideas. ${ }^{22}$

Secara harfiah dan sebagaimana digunakan dalam metafisika klasik, ideologi merupakan ilmu pengetahuan tentang ide-ide, studi tentang asal-usul ide-ide. Dalam penggunaan modern, ideologi mempunyai arti negatif sebagai teorisasi atau spekulasi dogmatik dan khayalan kosong yang tidak betul atautidak realistis; atau bahkan palsu dan menutupnutupi realitas yang sesungguhnya. Dalam arti positif, makna ideologi adalah setiap sistem gagasan yang mempelajari keyakinan-keyakinan dan hal-hal ideal filosofis, ekonomis, politis, sosial. Ideologi dalam pemahaman umum ini tidak hanya sekedar gagasan, melainkan gagasan yang diikuti dan dianut sekelompok besar manusia atau bangsa, sehingga dengan itu ideologi bersifat menggerakkan manusia untuk merealisasikam gagasan tersebut. Sepanjang sejarah peradaban Islam, dimana Islam dalam arti kebudayaan dan dalam arti ilmu-ilmu telah menjadi sekumpulan pemikiran teologis, interpretatif, historis, dan kata-kata yang digabungkan

\footnotetext{
22Gunawan Setiardja. 1993. Hak-Hak Asasi Manusia Berdasarkan Ideologi Pancasila. (Yogyakarta: Kanisius, 1993) Hal. 17
} 
bersama-sama guna membentuk apa yang dikenal sebagai ilmu-ilmu Islam serta masing-masing mempunyai bidang studi spesialisasinya sendiri. Kemudian yang dilakukan orang adalah mempelajari, memperoleh pengetahuan teknis dan menjadi seorang ahli dalam satu bidang tertentu.

Seseorang yang berangkat memahami Islam dalam arti sebuah ideologi, memahami bahwa Islam bukanlah spesialisasi ilmiah, melainkan perasaan yang dimiliki seseorang berkenaan dengan mazhab pemikiran sebagai satu sistem keyakinan dan bukan sebagai satu kebudayaan. Ini berarti memahami Islam sebagai sebuah ide dan bukan sebagai sekumpulan ilmu. Memiliki makna Islam sebagai suatu gerakan kemanusiaan, historis, dan intelektual, bukan sebagai gudang informasi teknis dan ilmiah. Dengan kata lain, ini juga berarti memandang Islam sebagai ideologi dalam fikiran seorangintelektual serta bukan sebagai ilmu-ilmu agama kuno dalam fikiran seorang ahli agama. Maka dari itu, Islamologi sudah sepatutnya diajarkan dengan cara demikian. Untuk sampai pada tujuan ini, perlu digambarkan umum perihal sebuah mazhab pemikiran dan menjelaskan makna mazhab pemikiran. Islam harus dipandang sebagai satu mazhab ideologis, bukan sebagai kebudayaan atau kumpulan ilmu. ${ }^{23}$

\footnotetext{
23Syariati Ali Syari'ati. Islam Mazhab Pemikiran dan Aksi, terj. M. S. Nasrulloh dan Afif Muhammad, cet. ke-2. (Bandung: Mizan, 1995). Hal. 18
} 
Mengambil penjelasan menurut pandangan Ali Syari'ati diatas, bahwa dalam menjelaskan tentang mazhab pemikiran sebagai satu ide atau gagasan dan kemudian menampilkannya dalam bentuk pola geometris. Ia menjelaskan mazhab pemikiran adalah sekumpulan konsep filosofis, keyakinan keagamaan, nilai-nilai etika, dan metode praktis yang harmonis melalui hubungan rasional dengan melahirkan suatu kesatuan yang dinamis, bermakna, terarah, dan terpadu yang hidup dan semua bagiannya dijiwai oleh satu ruh. ${ }^{24}$

Setiap diri akan mempunyai satu dimensi dari pandangan-pandangannya, dengan itu dapat diduga dimensi lain dari konsep-konsep intelektual atau intuisinya. Jika seseorang percaya pada mazhab pemikiran, maka kepercayaan, emosi, jalan hidup, politik, pandangan-pandangan sosial, konsep-konsep intelektual, keagamaan, dan etikanya tidaklah terpisah,

\section{Karakteristik Islamic worldview}

Worldview dapat dikatakan sebagai kepercayaan dan pikiran seseorang yang berfungsi sebagai asas atau motor bagi segala perilaku manusia. Jadi worldview adalah istilah netral yang dapat diaplikasikan ke dalam berbagai dinominasi agama, kepercayaan, atau lainnya. Sebab ia adalah faktor dominan dalam diri manusia yang menjadi penggerak dan

\footnotetext{
${ }^{24}$ Syariati Ali Syari'ati. Islam Mazhab Pemikiran dan Aksi, terj. M. S. Nasrulloh dan Afif Muhammad, cet. ke-2. (Bandung: Mizan, 1995). Hal. 19
} 
landasan bagi aktivitas seluruh kegiatan kehidupan manusia. ${ }^{25}$ Dalam tradisi pemikiran Islam sebenarnya juga terdapat faktor dominan dalam diri menentukan keberagaman dan juga kehidupan seseorang, tapi tidak memakai istilah, worldview secara eksplisit. Islam sebagai agama dan peradaban sebenarnya dapat ditangkap dari konsep $d i>n$ yang secara sistematik mirip dengan worldview. Namun, ketika konsep tersebut masuk dalam acara berfikir seseorang dan mempengaruhi tingkah laku, belum ada istilahnya yang baku.

Para ulama abad kedua puluh mengemukakan istilah berbeda untuk menggambarkan worldview, antara lain menurut al-Maududi istilah untuk Islamic worldview adalah Islami Nazariya $>t$ yaitu pandangan hidup yang dimulai dari konsep ke- Esaan Tuhan (syahadad) yang berimplikasi pada keseluruhan kegiatan manusia di dunia. Sebab shahadad adalah pernyataan moral yang mendorong manusia untuk melaksanakannya dalam kehidupan secara menyeluruh. Pengertian Islamic worldview menurut Atif al-Zayn adalah alMabda' al-Isla>mi, yaitu aqidah fikriyah (kepercayaan yang rasional) yang berdasarkan pada akal, sebab setiap muslim wajib beriman kepada hakikat wujud Allah SWT, kenabian Muhammad SAW, dan kepada al- Qur'an dengan akal, Iman kepada hal-hal yang gaib berdasarkan dengan cara

${ }^{25}$ Hamid Fahmy Zarkasy. "Islam Sebagai Pandangan Hidup", dalam Tantangan Sekularisasi dan Liberalisasi di Dunia Islam,. (Jakarta: Khairul Bayan Press, 2004). Hal. 4 
penginderaan yang diteguhkan oleh akal sehingga tidak dapat dipungkiri lagi. Iman kepada Islam sebagai di>n yang diturunkan melalui Nabi Muhammad SAW untuk mengatur hubungan manusia dengan Tuhan, dengan dirinya dan lainnya. Menurut Sayyid Quthb istilah yang tepat untuk Islamic worldview adalah al-Tasawwur al-Islami, yaitu akumulasi dari keyakinan asasi yang terbentuk dalam pikiran dan hati setiap muslim yang memberi gambaran khusus tentang wujud dan apa-apa yang terdapat di balik itu. ${ }^{26}$

Menurut Syed Muhammad Naquib al-Attas, Islamic worldview adalah visi tentang realitas dan kebenaran, yang terbaca oleh mata hati kita dan yang menerangkan tentang hakikat wujud yang sesungguhnya, sebab totalitas dunia wujud itulah yang diproyeksikan Islam. Oleh sebab itu, istilah worldview ini diterjemahkan oleh al-Attas ke dalam terminologi Islam (bahasa Arab) sebagai Ru'yat al-Isla>m li al-Wuju>d yang berarti pandangan terhadap hakikat dan kebenaran tentang alam semesta. Definisi para ulama tersebut di atas secara umum hampir sama, tapi jika dicermati lebih detail dan dihubungkan dengan gerakan yang mereka lakukan hanya menunjukkan perbedaan penekanan pada tingkat aksi. Definisi al-Maududi lebih berorientasi pada struktur kekuasaan politik yang membuka ruangbagi pelaksanaan ibadah yang luas,

\footnotetext{
26Hamid Fahmy Zarkasy. "Islam Sebagai Pandangan Hidup", dalam Tantangan Sekularisasi dan Liberalisasi di Dunia Islam,. (Jakarta: Khairul Bayan Press, 2004). Hal. 5
} 
Sayyid Quthb menekankan pada pandangan ideologis, sedangkan Syed Muhammad Naquib al-Attas lebih menekankan pada aspek epistemologisnya, yaitu penekanan pada aspek visi tentang realitas dan kebenaran.

Dibandingkan definisi umum worldview yang disebutkan sebelumnya, definisi para ulama tersebut di atas menunjukkan dua poin penting yakni sumbernya yang berasal dari wahyu dan aqidah, dan sudut pandangnya yang menjangkau realitas yang lebih luas. Dalam kondisi ketika serangan pemikiran dari pandangan hidup barat (western worldview) begitu gencar, penekanan epistemologi Syed Muhammad Naquib al-Attas sangat relevan. Sebab, apa yang membedakan suatu worldview, kebudayaan, atau agama dengan lainnya adalah dalam cara menafsirkan apa makna kebenaran dan realitas, dan itu termasuk dalam domain epistemologi yang berbasis pada pemahaman realitas di balik fisik (metafisika). Dalam menentukan sesuatu itu benar dan nyata setiap kebudayaan dipengaruhi oleh sistem metafisika masing-masing yang terbentuk oleh worldview. ${ }^{27}$

Sebelum memahami lebih jauh pandangan hidup Islam (Islamic worldview), kelahirannya dan perannya dalam melahirkan ilmu-ilmu dalam Islam, perlu dipaparkan terlebih dahulu karakteristik pandangan hidup Islam (Islamic

\footnotetext{
${ }^{27}$ Muhammad Naquib al-Attas,2001. Prolegomena to the Metaphysics of Islam: An Exposition of the Fundamental Elements of the Worldview of Islam. Kuala Lumpur: ISTAC. Hal. ix
} 
worldview), untuk lebih mendalam dalam tulisan ini berusaha mengupas dan membandingkan pandangan Sayyid Quthb dan Syed Muhammad Naquib al-Attas sebagai usaha memahamkan agar lebih muda dicerna. Dalam pandangan Sayyid Quthb karakteristik al-Tas\}awwur al-Isla>mi terdiri dari tujuh 28 , yaitu:

Pertama: ia bersifat Rabbani artinya berasal dari Tuhan sehingga dapat disebut visi keilahian. Sifat ini membedakan Islam dari worldview lain. Ia diturukan oleh Tuhan dengan segenap komponennya. Berbeda dengan Islam, worldview lain seperti pragmatism, idealism atau dialektika materialism bersumber dari akal pikiran dan kehendak manusia. Bahkan kitab suci agama lain selain Islam telah tercampur oleh pandangan akal pikiran manusia. Sedangkan Islam kitab sucinya masih terjaga (QS. Al- Hijr: 9).

Kedua: bersifat konstan tsabat artinya tas\}awwur al-Isla>mi itu tidak dapat diimplementasikan ke dalam berbagai bentuk struktur masyarakat dan bahkan berbagai macam masyarakat. Namun esensinya tetap konstan, tidak berubah, dan tidak berkembang. Ia tidak memerlukan penyesuaian terhadap kehidupan dan pemikiran, sebab ia telah menyediakan ruang dinamis yang bergerak dalam suatu kutub yang konstan. Alam semesta dengan sunnatullah, manusia dengan sifat

\footnotetext{
${ }^{28}$ M. Sayyid Quthb, , al-Tashawwur al-Islâmî wa Muqawamâtuhû, (Cairo: al-Babi alHalabi, 1962). Hal. 210
} 
kemanusiannya adalah desain yang konstan. Sifat konsisten ini berlawanan dengan perkembangan yang tidak terbatas yang terjadi di Barat dan bukan menjadi tameng bagi westernisasi atau pengaruh kebudayaan Eropa, nilai-nilai, dan metodologinya.Ketiga: Komprehensif syumu $>l$ artinya tas\}awwur al-Isla $>m i$ itu bersifat komprehensif. Sifat komprehensif ini didukung oleh prinsip tauhid yang dihasilkan dari sumber Tuhan yang Esa. Tauhid yang termanifestasikan ke dalam kesatuan antara pemikiran dan tingkah laku, antara visi dan inisiatif, antara doktrin dan sistem, antara hidup dan mati, antara cita-cita dan gerakan, antara kehidupan dunia dan kehidupan sesudahnya. Kesatuan ini tidak dapat dipecahpecah ke dalam bagian-bagian yang tidak saling bersesuaian, termasuk memisahkan anatara ibadat dan muamalat. Jika Islam dipahami di luar konsep tauhid ini, pemahaman itu dapat meletakkan seseorang diluar konsep Islam. ${ }^{29}$

Keempat: Seimbang tawazun artinya pandangan hidup Islam (Islamic worldview) merupakan keseimbangan antara wahyu yang dapat dipahami oleh manusia dan yang diterima dengan penuh keyakinan dan keimanan karena keterbatasan akal manusia. Selain itu keseimbangan ini juga berarti keseimbangan antara yang diketahui al-ma"lum dan yang tidak

${ }^{29}$ M. Sayyid Quthb, , al-Tashawwur al-Islâmî wa Muqawamâtuhû, (Cairo: al-Babi alHalabi, 1962). Hal.127 
diketahui ghair ma"lum, antara yang nyata dan yang tidak nyata.

Kelima: Positif $i j a>b i$, artinya dari aktivitas ketaatan kepada Allah SWT manusia menghasilkan sikap positif dalam hidupnya. Segala aktivitas dalam hidup manusia dan relevansinya dan konsekuensinya dalam agama. Pernyataan syahadad dalam lidah harus diaplikasikan ke dalam setiap amal.

Keenam: Pragmatisme al-waqi>'iyyah artinya sifat pandangan hidup Islam (Islamic worldview) itu tidak selau idealistis, tapi juga membumi ke dalam realitas kehidupan. Jadi, ia idealistis dan realistis yang sesuai dengan sifat-sifat kemanusiaan. Dalam Islam, peran manusia yang dibutuhkan hanyalah sejauh kapasitasnya sebagai manusia. Ia tidak diletakkan lebih rendah dari itu atau dituntut untuk berperan pada tingkat ketuhanan. Ia berbeda dari visi Brahma dalam agama Hindu yang menganggap raga manusia sebagai tidak riil, atau dari pandangan hidup Kristen (Kristen worldview) yang menganggap manusia terdiri dari jiwa dan raga, tapi menganggap segala yang berhubungan dengan raga sebagai kejahatan. ${ }^{30}$

Ketujuh: Tauhid, artinya karakteristik yang paling mendasar dari pandangan hidup Islam (Islamic worldview) adalah pernyataan bahwa Tuhan itu adalah Esa dan segala

\footnotetext{
${ }^{30}$ M. Sayyid Quthb, , al-Tashawwur al-Islâmî wa Muqawamâtuhû, (Cairo: al-Babi alHalabi, 1962). Hal. 206-210
} 
sesuatu diciptakn oleh-Nya. Karena itu tidak ada penguasa selain Dia. Tidak legislator selain Dia, tidak ada siapapun yang mengatur kehidupan manusia, hubungan dengan dunia, makhluk hidup atau manusia kecuali Allah. Petunjuk, undangundang, dan semua sistem kehidpan, norma atau nilai yang mengatur hubungan antara manusia dengan-Nya.

Karakteristik yang dikemukakan Sayyid Quthb menunjukkan luasnya jangkauan yang menjadi bidang cakupan pandangan hidup Islam (Islamic worldview), akan tetapi penggambaran tentang luasnya cakupan pandangan hidup Islam (Islamic worldview) menjadikan kurang detail. Untuk melengkapi gambaran pandangan hidup Islam (Islamic worldview).

Perlu juga dihadirkan pandangan Syed Muhammad Naquib al- Attas. ${ }^{31}$ (Zarkasy, 2004: 9). Menurutnya, pandangan hidup Islam (Islamic worldview) mempunyai elemen penting yang menjadi karakter utamanya. Elemen penting pandangan hidup Islam (Islamic worldview) itu digambarkan dalam poinpoin berikut ini:

Pertama: Dalam pandangan hidup Islam (Islamic worldview), realitas dan kebenaran dimaknai berdasarkan kepada kajian metafisika terhadap dunia yang nampak visible world dan yang tidak nampak invisible world. Sedangkan

\footnotetext{
${ }^{31}$ Hamid Fahmy Zarkasy. "Islam Sebagai Pandangan Hidup", dalam Tantangan Sekularisasi dan Liberalisasi di Dunia Islam,. (Jakarta: Khairul Bayan Press, 2004). Hal. 9
} 
pandangan Barat terhadap realitas dan kebenaran. Terbentuk berdasarkan akumulasi pandangan terhadap kehidupan kultural, tata nilai, dan berbagai fenomena sosial. Meskipun pandangan ini tersusun secara koheren, tapi sejatinya bersifat artificial. Pandangan ini juga terbentuk secara gradual melalui spekulasi filosofis dan pemenuan ilmiah yang terbuka untuk perubahan. Spekulasi yang terus berubah itu Nampak dalam dialektika yang bermula dari thesis kepada antithesis, dan kemudian synthesis. Juga dalam konsep tentang dunia, mulamula bersifat God centered. Perubahan-perubahan ini tidak lain dari adanya worldview yang berdasarkan pada spekulasi yang terus berubah karena perubahan kondisi social, tata nilai, agama, dan tradisi intelektual Barat.

Kedua: Pandangan hidup Islam (worldview) bercirikan pada metode berfikir yang tauhid integral. Artinya, dalam memahami realitas dan kebenaran pandangan hidup Islam (Islamic worldview) menggunakan metode yang tidak dikotomi, yang membedakan antara objektif dan subjektif, historisnormatif, tekstual-kontekstual dan sebagainya. Sebab dalam Islam, jiwa manusia itu bersifat kreatif dan dengan persepsi, imaginasi, dan intelegensinya ia berpartisipasi dalam membentuk dan menerjemahkan dunia indera dan pengalaman inderawi, serta dunia imajinasi. Karena worldview yang seperti itulah, tradisi intelektual di Barat diwarnai oleh munculnya berbagai sistem pemikiran yang berdasarkan pada 
materialism, pragmatism, dan lain-lain. Akibatnya, di Barat dua kutub metode pencarian kebenaran tidak pernah ketemu dan terjadilah cul de sac.

Ketiga: Pandangan hidup Islam (Islamic worldview) bersumberkan kepada wahyu yang diperkuat oleh agama dan didukung oleh prinsip akal dan intuisi. Karena itu pandangan hidup Islam telah sempurna sejak awal dan tidak memerlukan kajian ulang atau tinjauan kesejarahan untuk menentukan posisi dan peran historisnya. Subtansi agama seperti; nama, keimanan, dan pengalamannya, ritus-ritus, doktrin serta sistem teologisnya telah ada dalam pentas sejarah, Islam telah "dewasa" sebagai sebuah sistem dan tidak memerlukan pengembangan. Ia hanya memerlukan penafsiran dan elaborasi yang merujuk kepada sumber yang permanen itu. Sedangkan ciri pandang hidup Islam (Islamic worldview) adalah otentisitas dan finalitas. Lalu apa yang Barat disebut klasifikasi dan periodesisasi pemikiran, seperti periode klasik, pertengahan modern, dan postmodern tidak dikenal dalam pandangan hidup Islam. Periodesasi itu sejatinya menggambarkan perubahan elemen-elemen mendasar dalam worldview dan sistem nilai mereka.

Keempat: Elemen-elemen pandangan hidup Islam (Islamic worldview) terdiri utamanya dari konsep Tuhan, konsep wahyu, konsep penciptaan-Nya, konsep psikologi manusia, konsep ilmu, konsep agama, konsep kebebasan, konsep nilai dan 
kebajikan, konsep kebahagiaan. Elemen-elen mendasar yang kontekstual inilah yang menentukan bentuk change (perubahan), development (perkembangan) dan progress (kemajuan) dalam Islam. Elemen-elemen dasar ini berperan sebagai tiang pemersatu yang meletakkan sistem makna, standar tata kehidupan, dan nilai dalam suatu kesatuan sistem yang koheren dalam bentuk worldview.

Kelima: Pandangan hidup Islam (Islamic worldview) memiliki elemen utama yang paling mendasar yaitu konsep tentang Tuhan. Konsep Tuhan dalam Islam adalah sentral dan tidak sama dengan konsep-konsep yang terdapat dalam tradisi keagamaan lain, seperti dalam tradisi filsafat Yunani dan Hellenisme, tradisi filsafat Barat, atau tradisi mistik Timur dan Barat sekaligus. Kesamaan-kesamaan beberapa elemen tentang konsep Tuhan antara Islam dan tradisi lain tidak dapat dibawah kepada kesimpulan adanya satu Tuhan universal, sebab sistem konsektualnya berbeda. Karena itu ide Transendent Unity of Religion adalah absurd.

\section{Kesimpulan}

Hal yang paling utama yang harus diperhatikan dalam membangun peradaban umat adalah cara pandang terhadap Islam. Artinya pandangan umat Islam harus menggunakan pandangan atau cara berpikir yang berasas Islam, menghadirkan Islam dalam semua lini kehidupan baik Politik, Ekonomi, Pendidikan, Sains dan sektor-sektor lainnya. Sebab Islam yang 
bersumber dari Alquran membahas secara universal tentang politik. Tatanan pemerintahan yang sesuai agar bisa menjalankan syariat, bagaimana menata kehidupan yang baik dan wilayahnya bisa berdaulat dan bermartabat juga rakyatnya bisa sejahtera

Peradaban Islam adalah peradaban yang dibangun oleh ilmu pengetahuan Islam yang dihasilkan dari pandangan hidup Islam. membangun peradaban Islam harus dimulai dengan membangun pemikiran umat Islam, meskipun tidak berarti kita berhenti membangun bidang-bidang lain. Mengubah Islamicworldview/framework atau cara pandang umat kepada cara pandang Islam (prinsip Islam) adalah kunci bangkitnya peradaban Islam. Sebab peradaban itu muncul dari pandangan yang melahirkan tindakan dan berbuah Ilmu Pengetahuan.

Islamic worldview adalah pandangan hidup yang dimulai dari konsep ke-Esaan Tuhan (syahadad) yang berimplikasi pada keseluruhan kegiatan manusia di dunia.Islamic worldview diartikan juga sebagai visi tentang realitas dan kebenaran, yang terbaca oleh mata hati kita dan yang menerangkan tentang hakikat wujud yang sesungguhnya, sebab totalitas dunia wujud itulah yang diproyeksikan Islam.

Pembangunan ilmu pengetahuan Islam yang berasas dari cara pandang Islam hendaknya dijadikan prioritas bagi seluruh gerakan Islam. Walhasil dengan merealisasikan Islamic worldview dalam sanubari umat Islam, mudah-mudahan akan melahirkan semangat dalam mengembangkan ilmu pengetahuan Islam. 
Islamic Worldview Di Dunia Pendidikan

174 | AT-TUROTS: Jurnal Pendidikan Islam 


\section{DAFTAR PUSTAKA}

Al-Attas, S.M.N., 1996. "The Worldview of Islam, An Outline, Opening Adress", dalamSharifah Shifa al-Attas (ed.), Islam and the Challenge of Modernity, Proceeding of the inauguralSymposium on Islam and the Challenge of Modernity: Historical and Contemporary Context,Kuala Lumpur Agustus, 1-5, 1994, Kuala Lumpur: ISTAC

Acikgence, Alparslan. 1996 . "The Framework for A history ofIslamic Philosophy", Al-Shajarah, Journal of The International Institute of Islamic Thoughtand Civlization, vol.1. Nos. 1\&2, Kuala Lumpur: ISTAC.

Al-Zayn, Shaykh Âthif, 1989.al-Islâm wa Idulujiyyat al-Insân, Beirut: Dâr al- Kitâb al-Lubnânî.

Hung, Edwin, 1997. The Nature of Science: Problem and Perspectives, (California: Introduction, Wadsworth, Australia: Thomson Learning, London: Harper \& Brothers Publishers

Kuhn, Thomas S.1970, The Structure ofScientific Revolution, International Encyclopedia of Unified Science, vol.2, no 2, Chicago:Univerity of Chicago Press

Muhammad Naquib al-Attas,2001.Prolegomena to the Metaphysics of Islam: An Exposition of the Fundamental Elements of the Worldview of Islam. Kuala Lumpur: ISTAC

Quthb, M. Sayyid. 1962, al-Tashawwur al-Islâmî wa Muqawamâtuhî, Cairo: al-Babi al- Halabi.

Schumpeter, Joseph A, .1942. Capitalism, Socialism and Democarcy, New York : Charles Sribner's sons.

Setiardja, Gunawan, 1993. Hak-Hak Asasi Manusia Berdasarkan Ideologi Pancasila Yogyakarta: Kanisius, 1993 
Smart, Ninian,2000. Worldview, Crosscultural Explorations of Human Belief, New York: Charles Sribner's sons, (nd), 1-2.

Syari'ati, Ali. 1995. Islam Mazhab Pemikiran dan Aksi, terj. M. S. Nasrulloh dan Afif Muhammad, cet. ke-2. Bandung: Mizan

Wall, Thomas F. 2001.Thinking Critically About Philosophical Problem, A Modern Wardsworth. London: Harper \& Brothers Publishers

Zarkasy, Hamid Fahmy, 2004"Islam Sebagai Pandangan Hidup", dalam TantanganSekularisasi dan Liberalisasi di Dunia Islam, ed. Tim KB Press . Jakarta: Khairul Bayan 